\title{
THE CRIB II (CLINICAL RISK INDEX FOR BABIES II) SCORE IN PREDICTION OF NEONATAL MORTALITY
}

\author{
Orhideja Stomnaroska ${ }^{1}$, Dragan Danilovski ${ }^{2}$ \\ ${ }^{1}$ University Clinic for Gynecology and Obstetrics, Medical Faculty Skopje, Skopje, RN Macedoniaa \\ ${ }^{2}$ Institute for Epidemiology and Biostatistics, Medical Faculty Skopje, Skopje, RN Macedonia
}

Corresponding author: Orhideja Stomnaroska, University Clinic for Gynecology and Obstetrics, Medical Faculty Skopje, 1000 Skopje, RN Macedonia; e-mail: stomnaroskao@yahoo.com

\begin{abstract}
Predicting the outcome of neonatal critical patients remains elusive. The multiple factors of maternal state of health (infections, diabetes, gestosis), the placental situation (premature rupture of membranes) as well as multiple factors from the baby (small for gestational age, low Apgar score, low birth infections, mechanical ventilation, hypoglycaemia hyperglycamiea) render the approach to treatment of each patient individual and the outcome uncertain. Several approaches and scales are developed in order to assess the mortality risk in those rather complicated situations.

We used the CRIB-II scale to assess the mortality risk in 80 patients delivered in a large tertiary level hospital with more than 4,000 deliveries yearly. The patients were stratified according to all the neonatal risk factors and comorbidities. The CRIB-II scale identified well the mortality rates, but not the outcomes. A large and well-balanced cohort of patients followed for a longer period is required to discern in detail the importance of CRIB-II scale in predicting outcomes in high-risk new-borns. This could serve as an assistance to personalized approach to severely sick children. In addition, it is a valuable method in comparing outcomes in different NICUs and outcomes in different times in the same NICU, thus rendering possible improvements in the same unit and among several NICU departments.
\end{abstract}

Keywords: neonatal mortality, high-risk babies, CRIB-II score

\section{INTRODUCTION}

Neonatal mortality is high in countries with lower socioeconomic status (Burstein et al. 2019 [1], Howell et al. 2018 [2]). One of the most important factors is the prematurity: moderate to late preterm babies (32-36 weeks), very preterm babies (28-31 weeks) and extremely preterm babies ( $<28$ weeks). Birth weight, especially children with low and very low weight are also new-borns with increased risk. The presence or absence of maternal factors of risk (diabetes, maternal infections, eclampsia...) is also influencing the outcome and mortality. The same goes for hypoxic-ishaemic syndrome and various types of infections in newborns. The way of delivery, vaginal versus caesarean, is also of significance. The neonatal mortality depends on sociodemographic, obstetrical, psychological, and genetic factors. Paternal and environmental factors are also involved. Pregnancy complications and the context of delivery 
also have an impact on the neonatal outcomes. All those factors contribute not only for the high mortality rates in neonates but also for a significant numbers of children with neurological problems and mental retardation. Several scales - SNAPPE, SNAPPE-II $[3,4,5]$ and CRIB-II $[6,7,8]$ have been developed in order to determine the outcome and mortality in high-risk babies. This would add to personalizing their treatment and possibly improve the outcome.

\section{PATIENTS AND METHODS}

We investigated 80 newborns delivered at the Clinic for Gynecology and Obstetrics ( 4,000 deliveries yearly). The institutional ethics committee approved the study. We excluded children with congenital malformations and polycythemia. We assessed the gestational age, weight and length, Apgar score, delivery mode, children with infections (pneumonia, sepsis...), children with hypoxic ischemic syndrome, children whose mothers have toxemia, addictions, diabetes, or chorioamnionitis. Blood biochemistry (electrolytes, blood glucose, liver probes and enzymes, urea and creatinine), inflammatory markers (white blood cell counts, CRP), acid-base balance were also recorded. Microbiological investigations (tracheal swabs, urine and blood cultures), ultrasound of the head and/or kidneys, X-rays of the chest were also performed as indicated. The ABL700 analyzation (Radiometer Medical A/S, Copenhagen, Denmark) was used for blood biochemistry analysis.

To assess the risk in newborns we used the CRIB-II scale [3-8]. The scale uses five parameters: gender, body weight, the worst basis excess, body temperature and referral.

The statistical analysis through Excel and SPSS with standard descriptive and analytical methods was used. The paired samples statistics and the paired samples test (T-test) assessed the differences on the CRIB-II scale.

\section{RESULTS}

In this study we investigated 80 babies ( $\mathrm{M}: \mathrm{F}=60: 40$ ) delivered at the Clinic of Gynecology and Obstetrics in the period 2018-2020. Low birth weight was found in all children. Very low birth weight $(<1,500 \mathrm{gr})$ was found in 36 children $(45 \%)$, low birth weight $(1,500-2,500 \mathrm{~g})$ in 44

Table 1. Patient characteristics

\begin{tabular}{|c|c|c|c|}
\hline \multicolumn{4}{|l|}{ Birth weight } \\
\hline & & Very low birth weight $(<1,500$ gr $)$ & $36 \quad(45,00 \%)$ \\
\hline & & Low birth weight $(1,500-2,500 \mathrm{gr})$ & $44 \quad(55,00 \%)$ \\
\hline & & Appropriate birth weight & None \\
\hline & & High birth weight ( $>4,000$ gr) & None \\
\hline \multicolumn{4}{|l|}{ Gestational week } \\
\hline & & $20-25 \mathrm{gn}$ & None \\
\hline & & $26-30 \mathrm{gn}$ & $25 \quad(31.25 \%)$ \\
\hline & & $31-35 \mathrm{gn}$ & $52 \quad(65 \%)$ \\
\hline & & $36-40 \mathrm{gn}$ & $2 \quad(2.5 \%)$ \\
\hline \multicolumn{4}{|l|}{ Comorbidities } \\
\hline & & HIE & $(6.25 \%)$ \\
\hline & & HIC & $5 \quad(6.25 \%)$ \\
\hline & & Sepsis, Pneumonia & $22 \quad(27.5 \%)$ \\
\hline \multicolumn{4}{|l|}{ Delivery } \\
\hline & & Cesarean section & $52 \quad(65 \%)$ \\
\hline & & Presenatio capitis & $56 \quad(70 \%)$ \\
\hline & & Presentatio caudae & $(13.75 \%)$ \\
\hline & & Presentatio pedis & $4 \quad(5 \%)$ \\
\hline & & Situs transverses (Cesarean section) & $9 \quad(11.25 \%)$ \\
\hline \multicolumn{4}{|l|}{ Risk factors from mother } \\
\hline & & Colpitis / infection & $10 \quad(12.5 \%)$ \\
\hline & & DM gestational & $(1.25 \%)$ \\
\hline & & Preeclampsia/Eclampsia & $(10 \%)$ \\
\hline \multicolumn{4}{|l|}{ Placental factors } \\
\hline & & Placental abruption & $6 \quad(7.5 \%)$ \\
\hline & & Umbilical cord draped around neck & $8(10 \%)$ \\
\hline
\end{tabular}


(55\%). There were no children born appropriate for gestational age or large for gestational age.

Low birth age children dominated: twenty five babies (31.25\%) were born between 26-30 gestational week $(\mathrm{GW})$, while $52(65 \%)$ were born between $31-35 \mathrm{GW}$ and two babies $(1.6 \%)$ between 36-40 GW. There were no babies delivered between 20-25 GW.

Caesarean section was observed in $52(65 \%)$ babies and vaginal delivery in $28(35 \%)$. Ten mothers $(12.5 \%)$ had various infections during pregnancy, while five of them $(6.25 \%)$ had toxaemia and one diabetes mellitus $(1.25 \%)$. There were six placental abruptions (7.5\%).

Comorbidities were also frequent: five babies $(6.25 \%)$ had hypoxemic-ischaemic encephalopathy, $22(27.5 \%)$ had infections, 5 (6.25\%) intracranial bleeding, and 7 (8.75\%) low calcium levels. Hypoglycaemia $(\mathrm{HG})$ was found in $80(100 \%)$ children, and symptomatic HG with seizures in $3(2.4 \%)$. Nine children (11.25\%) died.

Neonatal mortality significantly correlated with the gestational age $(p>0.01)$, maternal comorbidities ( $p>0.05$ ), but not with the birth weight $(p>0.05)$. The lowest Apgar score was in positive correlation with the gestational age $(p>0.01)$, but not with the birth weight ( $\mathrm{p}>0.05)$.

The initial mortality risk assessed with CRIB II in low birth weight new-borns resulted in

ROC curve (Receiver Operating Characteristic) with high sensitivity (true positives) and specificity (false positives) (the hugging curve). In contrast, curves with low sensitivity and specificity should be near the 45 degrees line (Fig. 1) [9]. Therefore, CRIB II functions well in determining which babies are going to succumb or survive the critical state.

Figure 1. ROC curve (Receiver Operating Characteristic) for CRIB II sensitivity and specificity

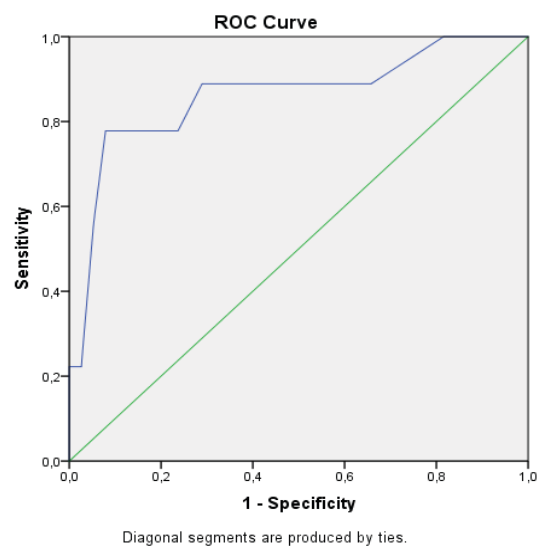

The Area Under the Curve (AUC) is an indicator of how well the model distinguishes between positive and negative outcomes [10]. Our logistic regression result of 0.861 points out that the CRIB II model functions well in foreseeing whether a certain child is going to survive or not.

When looking at the gestational age as a mortality risk in children with low birth weight the AUC value is 0.923 , which again points toward the reliability of CRIB II as a prediction tool. The form of the ROC curve confirms the same conclusion.

Figure 2. ROC curve (Receiver Operating Characteristic) for CRIB II for new-borns with low gestational age and low birth weight

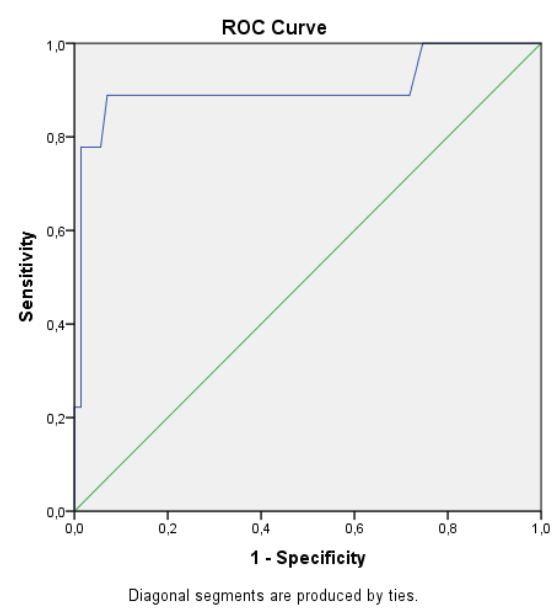

Table 3. Area Under the Curve (AUC) for CRIB II and gestational age, birth weight and hypoglycaemia

\begin{tabular}{|c|c|}
\hline Gestational age & 0,923 \\
\hline Birth weight & 0,904 \\
\hline Crib II & 0,861 \\
\hline Hypoglycaemia & 0,545 \\
\hline
\end{tabular}

Therefore, gestational age and birth weight have an excellent mortality predictive value (AUC 0.923 and 0.904 ). They are better in predicting lethality than the CRIB II score which has, however a good value of 0.861 . Hypoglycaemia with the AUC value of 0.545 has poor individual lethality predictive value.

\section{DISCUSSION}

Several groups of new-borns are high-risk babies $[1,2,11]$. They include large for gestational age (LGA), small for gestational age (SGA), 
new-borns under the 10th percentile, neonates with intrauterine growth restriction (23-32), gestational age under 37 weeks, neonates with sepsis, children of mothers with eclampsia or chorioamnionitis or diabetes.

There are several neonates sickness scores for assessment of disease severity, outcome and mortality [5]. Good predictive values of CRIB II were found in several studies in the neonatal intensive care units [7, 12]. Among 3,268 infants 317 (9.7\%) CRIB II (-T; without admission temperature) had excellent predictive characteristics: the overall $p=0.53$ [8]. In Kenia NICY 135 patients with: birth weight $<1,500 \mathrm{~g}$, base excess $<-12$ $\mathrm{mmol} / \mathrm{l}$, gestational age $<30$ weeks, temperature at admission $>37.5$ or $<35$ (all components of CRIB II) - were all found to be significantly associated with neonatal mortality [13]. In this report, the CRIB II score had a sensitivity of $80.6 \%$, specificity of $75.3 \%$, and a predictive value of $77.7 \%$ [13].

In a systematic review and meta-analysis [6] of six neonatal illness severity scores (CRIB, CRIB II, SNAP, SNAP II, SNAP-PE, and SNAPPE II), birthweight (BW), and gestational age (GA) the authors used PubMed, EMBASE, and Scopus as data sources published before January 2019. It is of note that only 24 out of 1,659 studies satisfied the inclusion criteria (McLeod et al. 2020) [6]. The CRIB index was the most accurate in predicting the pre-discharge mortality [AUC $0.88(0.86-0.90)]$, while the GA was the least discriminate [AUC $0.76(0.72-0.80)$ ] [6].

In 564 infants with extremely low birth weight, the GA, BW, Apgar score, CRIB II score and serum albumin levels were the best predictors for mortality during $\leq 7$ th and $>7$ th postnatal days [14].

Buhrer et al. 2000 [15] found that for combined poor outcome CRIB, the minimum and maximum FIO2 were independent predictors. Interestingly, out of 1,485 consecutive VLBW CRIB-II did not result in improved estimation of mortality risk in VLBW infants as compared to the CRIB, gestational age or birth weight [16].

The CRIB II score is a valid tool of initial risk assessment in LBW, predicting outcome more accurately than birth weight or gestational age alone [17[. The CRIB-II scores were also found to have the advantage of being simpler to collect and to calculate [18].
It is of note that scores are also useful in comparative quality assessment when comparing data in different NICU [3].

In our patients, the gestational age and birth weight have an excellent mortality predictive value (AUC 0.923 and 0.904). They are better in predicting lethality than the CRIB II score which has, however a good value of 0.861 . Although the use of neonatal scores is still a subject of many discussions [19] CRIB II has a well-established value in predicting neonatal outcomes. It is therefore possible to use CRIB II as a tool for following the outcomes in one NICU and combining the same tool in observing and ameliorating outcomes in different NICUs.

\section{REFERENCES}

1. Burstein R, Henry NJ, Collison ML, Marczak LB, Sligar A, Watson S, et al. Mapping 123 million neonatal, infant and child deaths between 2000 and 2017. Nature. 2019; 574 (7778): 353358.

2. Howell EA, Janevic T, Hebert PL, Egorova NN, Balbierz A, Zeitlin J. Differences in Morbidity and Mortality Rates in Black, White, and Hispanic Very Preterm Infants Among New York City Hospitals. JAMA Pediatr. 2018; 172(3): 269-277. Free PMC article.

3. Richardson DK, Tarnow-Mordi WO, Escobar GJ. Neonatal Risk Scoring Systems. Can They Predict Mortality and Morbidity? Clin Perinatol 1998; 25(3): 591-611.

4. Richardson DK, Corcoran JD, Escobar GJ, et al. SNAP-II and SNAPPE-II: simplified newborn illness severity and mortality risk scores. J Pediatr 2001; 138: 92-100.

5. Garg B, Sharma D, Farahbakhsh N. Assessment of sickness severity of illness in neonates: review of various neonatal illness scoring systems. J Matern Fetal Neonatal Med. 2018; 31(10): 1373-1380.

6. McLeod JS, Menon A, Matusko N, Weiner GM, Gadepalli S, Barks J, Mychaliska GB, Perrone EE Comparing mortality risk models in VLBW and preterm infants: systematic review and meta-analysis. Journal of Perinatology (40), 695703(2020).

7. Parry G, Tucker J, Tarnow-Mordi WO. CRIBII: an update of the clinical risk index for babies score. Lancet 2003; 361: 1789-1791.

8. Manktelow BN, Draper ES, Field DJ. Predicting neonatal mortality among very preterm infants: a comparison of three versions of the CRIB score. 
Arch Dis Child Fetal Neonatal Ed. 2010; 95(1): F9-F13.

9. How to Create and Interpret a ROC Curve in SPSS https://www.statology.org/roc-curve-spss/

10. The Area Under an ROC Curve http://gim.unmc. edu/dxtests/roc3.htm

11. Stomnaroska O. Neonatal hypoglycaemia in children with high and normal risk: incidence, aetiology, therapeutics and prognosis. Doctoral thesis, Medical Faculty Skopje, University Saints Cyril and Methodius, 2017.

12. Guenther K, Vach W, Kachel W, Bruder I, Hentschel R. Auditing Neonatal Intensive Care: Is PREM a Good Alternative to CRIB for Mortality Risk Adjustment in Premature Infants? Neonatology. 2015; 108(3): 172-8.

13. Marete IK, Wasunna AO, Otieno PA.East Afr Med J. Clinical risk index for babies (CRIB) II score as a predictor of neonatal mortality among low birth weight babies at Kenyatta National Hospital. 2011; 88(1): 18-23.

14. Jae Hyun Park, Yun Sil Chang, So Yoon Ahn, Se In Sung, Won Soon Park.. Predicting Mortality in Extremely Low Birth Weight Infants: Comparison between Gestational Age, Birth Weight, Apgar Score, CRIB II Score, Initial and Lowest
Serum Albumin Levels. PLoS One 2018; 13(2): e0192232.

15. Buhrer C, Grimmer I, Metze B, Obladen M. The CRIB (Clinial Risk Index for Babies) score and neurodevelopmental impairment at one year corrected age in very low birth weight infants. Intensive Care Med. 2000; 26: 325-9.

16. Ezz-Eldin ZM, Hamid TAA, Youssef MRL, Nabil HED.. Clinical Risk Index for Babies (CRIB II) Scoring System in Prediction of Mortality in Premature Babies. 2015; 9(6): SC08-11.

17. Bührer C, Metze B, Obladen M. CRIB, CRIB-II, Birth Weight or Gestational Age to Assess Mortality Risk in Very Low Birth Weight Infants? Acta Paediatr 2008; 97(7): 899-903.

18. Reid S, Bajuk B, Lui K, Sullivan EA, NSW, ACT Neonatal Intensive Care Units Audit Group PSN. Comparing CRIB-II and SNAPPE-II as mortality predictors for very preterm infants. J Paediatr Child Health. 2014; 51: 524-28.

19. Jašič M, Dessardo NS, Dessardo S, Rukavina KM. CRIB II score versus gestational age and birth weight in preterm infant mortality prediction: who will win the bet? SIGNA VITAE 2016; 11(1): 172-181. 


\title{
Резиме
}

\section{ВРЕДНОСТА НА СRIВ-II (КЛИНИЧКИ РИЗИК КАЈ БЕБИЊА) ВО ПРЕДИКЦИЈА НА МОРТАЛИТЕТОТ КАЈ НОВОРОДЕНЧИҢАТА}

\author{
Орхидеја Стомнароска ${ }^{1}$, Драган Даниловски ${ }^{2}$ \\ ${ }^{1}$ Универзитетска клиника за гинекологија и акушерство, Медицински факултет, \\ Скопје, РС Македонија \\ ${ }^{2}$ Институт за епидемиологија и биостатистика, Медицински факултет, Скопје, РС Македонија
}

Прогнозата на исходот кај критично болните неонатални пациенти останува да биде дефинирана .Многубројните фактори, од страна на здравјето на мајката (инфекции, дијабетес, гестози), плацентарните фактори (предвремено кинење на мембраните), како и многубројните фактори од страна на бебето (мали за гестациската возраст, низок Апгар-скор, механичка вентилација, хипогликемија, хипергликемија, инфекции) ја отежнуваат процената за исходот на болеста кај пациентите.

Постојат неколку методи, скали за процена на ризикот кај болното новороденче. Ние ја иследивме скалата CRIB-II за да го процениме ризикот од смрт кај 80 пациенти иследени во голема болница со околу 4000 раѓња годишно. Пациентите беа стратифицирани според сите фактори за ризик и коморбидитет кај новородени деца. Алатката CRIB-II се покажа дека добро го проценува морталитетот. Очигледно е дека е потребна студија на поголем број пациенти со урамнотежена распределба на ризиците и факторите на болеста за да се утврди корисноста на алатката CRIB-II во претскажувањето на исходот на ризичните новородени деца. Овој пристап би бил користен за персонализиран пристап за секој пациент. Исто така, методата би имала значителна вредност за споредба на исходите на лекување во иста единица на интензивна нега, како и за споредување на резултатите меѓу различни единици на неонатална интензивна нега.

Клучни зборови: неонатална смртност, бебиња со висок ризик, CRIB 